\title{
Localised atmospheric corrosion of magnesium-aluminum alloys produced by semi solid casting - A 2D and 3D investigation
}

\author{
M. Shahabi-Navid*, M. Halvarsson**, J.E., Svensson***, A. Allanore****, N. Birbilis*****, \\ L.G. Johansson***, M. Esmaily**** \\ * Volvo Group Trucks Technology, Gothenburg, Sweden \\ ** Department of Physics, Chalmers University of Technology, Gothenburg, Sweden \\ *** Department of Chemistry and Chemical Engineering, Chalmers University of Technology, Gothenburg, Sweden \\ **** Department of Materials Science and Engineering, Massachusetts Institute of Technology, Cambridge, United States \\ ***** College of Engineering and Computer Science, The Australian National University, Canberra, Australia
}

\begin{abstract}
The localised corrosion of two magnesium-aluminium alloys produced by a semi-solid casting method was studied herein. Specifically, atmospheric corrosion, which comparatively less widely studied in the case of magnesium alloys, was explored for the alloys AM50 and AZ91. Gravimetry confirmed the beneficial effect from ambient levels of carbon dioxide $\left(\mathrm{CO}_{2}\right)$ in suppressing corrosion through the formation magnesium hydroxy carbonates. Both $2 \mathrm{D}$ and $3 \mathrm{D}$ characterisation revealed that ambient $\mathrm{CO}_{2}$ has a strong influence on the morphology and rate of localised corrosion. $\mathrm{A} \mathrm{CO}_{2}$-free atmosphere resulted in the formation of deep, clustered and interconnected corrosion, whereas ambient $\mathrm{CO}_{2}$ resulted in isolated and shallow surface corrosion. The results herein support the notion that the $\mathrm{CO}_{2}$ induced acidity causes neutralisation of the catholyte, diminishing the activity of the cathodic areas and inhibiting $\mathrm{NaCl}(a q)$ droplet coalescence.
\end{abstract}

Keywords: Magnesium- aluminium alloys; Atmospheric corrosion; Localised corrosion; 3D imaging. 


\section{Introduction}

Among the various magnesium alloy systems, magnesium-aluminum ( $\mathrm{Mg}-\mathrm{Al})$ alloys are a key lightweight metallic material for the transportation industry - owing to their high specific stiffness, excellent damping properties, castability, and strength to weight ratio $[1,2]$. The broader use of such energy-efficient alloy systems in the automotive sector is still however limited, owing in part to limited corrosion resistance [1,2].

The inadequate corrosion resistance of $\mathrm{Mg}$ is because of its high electronegative potential or its low relatively thermodynamic stability $\left(\mathrm{E}^{\circ}=-2.4 \mathrm{~V}\right.$ vs. Standard hydrogen electrode (SHE)), and the unprotective (non-passivating) nature of the surface film that it forms upon the exposure to most practical aqueous environments. The oxide/hydroxide $\left(\mathrm{MgO} / \mathrm{Mg}(\mathrm{OH})_{2}\right)$ film, is indeed soluble in water (neutral and acidic aqueous solutions) and any partial failure in the surface film triggers localised corrosion on the metal surface [1-3].

In service conditions, degradation of $\mathrm{Mg}$ alloys mainly occurs under natural and anthropogenic environments (i.e. in the presence of relative humidity $(\mathrm{RH})$, deicing salts, atmospheric pollutants). The $\mathrm{NaCl}$-induced atmospheric corrosion of $\mathrm{Mg}$ and its alloys is considered to be predominantly electrochemical, similar to the process described to occur under aqueous environments [1,3]. This involves the anodic dissolution of $\mathrm{Mg}$ (Equation 1), water reduction (Equation 2), which leads to hydrogen evolution and the formation of hydroxy ions, as one of the dominant cathodic reactions, and the two reactions (Equations 1 and 2) that leads the formation of magnesium hydroxide (Equation 3) [1]:

$$
\begin{aligned}
& \mathrm{Mg}(s) \rightarrow \mathrm{Mg}^{2+}(a q)+2 e^{-} \\
& 2 \mathrm{H}_{2} \mathrm{O}+2 e^{-} \rightarrow \mathrm{H}_{2}(a q)+2 \mathrm{OH}^{-}(a q) \\
& \mathrm{Mg}^{2+}(a q)+2 \mathrm{OH}^{-}(a q) \rightarrow \mathrm{Mg}(\mathrm{OH})_{2}(s)
\end{aligned}
$$

The corrosion process establishes $\mathrm{pH}$ gradients between cathodes (that have a locally elevated $\mathrm{pH}$ owing to being sites of hydroxy ion formation (Equation 2)) and the anodic areas, where $\mathrm{pH}$ is approximately neutral. Owing to the solubility of the imperfect $\mathrm{MgO} / \mathrm{Mg}(\mathrm{OH})_{2}$ films at low $\mathrm{pH}$, the anodic reaction can continue unhindered (thus, in the range $\mathrm{pH} \mathrm{2-8,} \mathrm{the} \mathrm{rate} \mathrm{of} \mathrm{Mg}$ dissolution increases exponentially with $\mathrm{pH}$ ). This is significant because $\mathrm{Mg}$ corrosion is known to be under cathodic control (see e.g. [4]). There is no rate limitation for the cathodic reaction in the presence of water (Equation 2), i.e. the species being reduced is abundant and this is what the key difference is between systems where oxygen reduction is one of the partial reactions.

Hence, the electrochemical corrosion of $\mathrm{Mg}$ can be rapid, especially when the surface water film contains dissolved salts $[1,3,5]$. In addition to such electrochemical processes, the $\mathrm{pH}$ of the electrolyte on the alloy surface is strongly influenced by the gases present in the atmosphere. For instance, in highly polluted areas and under humid conditions, the $\mathrm{Mg}$ surface becomes an efficient getter for $\mathrm{SO}_{2}$ owing to the high $\mathrm{pH}$ of the thin electrolyte layer [6]. The outcome is the formation of two highly acidic species, namely hydrogen sulfite $\left(\mathrm{HSO}_{3}{ }^{-}\right)$and sulfite $\left(\mathrm{SO}_{3}{ }^{2-}\right.$ ) that results in a rapid dissolution of the $\mathrm{MgO} / \mathrm{Mg}(\mathrm{OH})_{2}$ surface film [6]. Another significant example is ambient concentrations of $\mathrm{CO}_{2}$ gas, which is always present in air at a concentration 
of around $400 \mathrm{ppm}$ [5]. This gas inhibits the corrosion of $\mathrm{Mg}$ alloys, both under atmospheric $[1,7,8]$ and aqueous [9] environments, which has also been attributed to the $\mathrm{CO}_{2}$-induced alterations in the electrolyte $\mathrm{pH}$. The process involves neutralising the alkali generated in the cathodic process (Equation 4) leading to the formation of magnesium hydroxy carbonates $\left(\mathrm{Mg}_{5}\left(\mathrm{CO}_{3}\right)_{4}(\mathrm{OH})_{2} \times x \mathrm{H}_{2} \mathrm{O}\right.$, where $\left.x=4-8\right)$, see e.g. Equation $5[1,8]$ :

$$
\begin{aligned}
& \mathrm{CO}_{2}(g)+2 \mathrm{OH}^{-}(a q) \rightarrow \mathrm{CO}_{3}{ }^{2-}(a q)+\mathrm{H}_{2} \mathrm{O}(\mathrm{l}) \\
& 5 \mathrm{Mg}^{2+}(a q)+4 \mathrm{CO}_{3}{ }^{2-}(a q)+2 \mathrm{OH}^{-}(a q)+4 \mathrm{H}_{2} \mathrm{O}(\mathrm{l}) \rightarrow \mathrm{Mg}_{5}\left(\mathrm{CO}_{3}\right)_{4}(\mathrm{OH})_{2} \times 4 \mathrm{H}_{2} \mathrm{O}(\mathrm{s})
\end{aligned}
$$

Magnesium hydroxy carbonates (e.g. Equation 5) formed on the alloy surface in the presence of $\mathrm{CO}_{2}$ have been reposted to be protective $[1,8]$ (the equilibrium $\mathrm{pH}$ of water in contact with $\mathrm{Mg}(\mathrm{OH})_{2}$ is 10.3 , whereas the corresponding value for magnesium hydroxy carbonate, hydromagnesite $\left(\mathrm{Mg}_{5}\left(\mathrm{CO}_{3}\right)_{4}(\mathrm{OH})_{2} \times 4 \mathrm{H}_{2} \mathrm{O}\right)$ is 8.7 [1]). The interactions between all the abovementioned electrochemical processes and the inhomogeneous microstructure of cast alloys can generate an intricate corrosion microstructure. When $\mathrm{Mg}$ is alloyed, the second phase particles and noble inclusions further enhance the corrosion process through activating micro-galvanic corrosion cells (i.e. localised corrosion). While the effects of the structural features (including different phases and defects) on localised corrosion of $\mathrm{Mg}$-based alloys in various environments have been extensively studied in the literature [9-18], the role played by the main atmospheric gasses in the localised corrosion is, by comparison, less widely studied.

One approach to investigate the localised atmospheric corrosion of alloys is to complement the "traditional" 2D methods by 3-dimensional (3D) methods using e.g. focus ion beam (FIB) milling microscopy (i.e. the Dual-beam systems). There are a very few studies on 3D investigation of corrosion carried out for: aluminum alloys [19], steels [20, 21], and Mg alloys [22]. In the latter case, using 3D imaging and correlative imaging, Krebs et al. [22] suggested that the development of the corrosion front in AZ31 Mg alloy (exposed to a saline environment) could be linked to Al-Mn second phase particles.

Herein, the localised corrosion of AM50 and AZ91 exposed for up to $672 \mathrm{~h}$ at $22^{\circ} \mathrm{C}$ and $95 \%$ $\mathrm{RH}$ in the presence and absence of $\mathrm{CO}_{2}$ was studied. In order to resolve the effect of $\mathrm{CO}_{2}$ on the extent of localised corrosion, the results obtained by 2D techniques were supplemented by $3 \mathrm{D}$ characterisation using FIB and interference microscopy. In addition, the influence of $\mathrm{CO}_{2}$ on the corrosion rate, the formation and growth of locally corroded areas was discussed. The alloys studied here were manufactured by a semi-solid casting method, rheocasting (RC) [23, 24]. Rheocasting produces alloys with a lower fraction of casting defects and microstructures that are slightly different from those of their high pressure die cast counterparts [24-26]. 


\section{Experimental}

\subsection{Sample Preparation}

RC technique, as described in the previous publications [23, 24], was utilized in order to prepare the SSC samples. The RC AM50 and RC AZ91 alloys were prepared using a vertical casting machine with a locking force of 50 tons. The machine can cast parts with a maximum projected area of $250 \mathrm{~cm}^{2}[24,27]$. The alloys investigated are high purity $\mathrm{Mg}-\mathrm{Al}$ alloys AM50 and AZ91, see Table I for the chemical composition.

\section{Table I}

The test coupons were machined as rectangular cuboids (approximate dimensions of $15 \times 15 \times 2$ $\mathrm{mm}^{3}$ ) with a geometrical area of about $5.7 \mathrm{~cm}^{2}$. The samples were wet-ground on $\mathrm{SiC}$ paper followed by two polishing steps with 3 and $1 \mu \mathrm{m}$ diamond paste. A suspension of colloidal silica in water (OPS) was used in the finishing step. The cleaned and dried samples were kept in a desiccator over a desiccant for $24 \mathrm{~h}$ before exposure. $\mathrm{NaCl}$ was applied to the polished samples before exposure by spraying a saturated solution of $\mathrm{NaCl}$ in an $80 / 20$ mixture of ethanol and water. Two levels of salt (i.e. 14 and $70 \mu \mathrm{g} / \mathrm{cm}^{2}$ ) were used. The salt was evenly distributed on the surface. Samples without salt were also exposed as references. Duplicate and triplicate samples were exposed.

\subsection{Gravimetric Analysis}

Exposures were performed at $22 \pm 0.03^{\circ} \mathrm{C}$ at a constant $\mathrm{RH}$ of $95 \pm 0.3 \%$ and lasted for $672 \mathrm{~h}$. The exposures in the presence of $400 \pm 20 \mathrm{ppm} \mathrm{CO}_{2}$ were performed in flowing air using an experimental set-up described elsewhere $[1,26,28]$. The $\mathrm{CO}_{2}$-free exposures were carried out in a closed container where a $\mathrm{KOH}(\mathrm{aq})$ solution was used to capture the $\mathrm{CO}_{2}$ and also to set the $\mathrm{RH}$ at $95.0 \%$. The samples were weighed regularly using a six decimal balance to record the increase in mass. After discontinuing the corrosion experiment the samples were stored for $24 \mathrm{~h}$ over a desiccant. The mass gain recorded after drying is termed 'dry mass gain'. Metal loss was determined using a pickling procedure that involved a $20 \% \mathrm{CrO}_{3}$ (aq) solution and ultrasonic agitation [26].

\subsection{Characterisation of the corrosion products}

Crystalline compounds were identified using a Siemens D5000 X-ray diffraction (XRD) system with a Göbel mirror using $\mathrm{CuK} \alpha$ radiation $(\lambda=1.5418 \AA$ ). Data were acquired in the range of 20: $5-80^{\circ}$ in $0.05^{\circ}$ increments using Grazing angle Incidence arrangement (GI-XRD).

The microstructure of the as-cast material and the morphology of the corroded surfaces were investigated by FEI Quanta 200 scanning electron microscope (SEM) and Ultra 55 FEG SEM. Carl Zeiss AxioVision image analysis software was employed to measure the area fraction of the Mg-Al intermetallic particles ( $\beta$-phase). A $1 \%$ nital etchant was used to reveal the alloys microstructure. The SEM used in the present study was equipped with an Oxford Inca energy dispersive X-ray spectroscopy (EDXS) system, which was utilized to perform local chemical analysis and elemental mapping. The EDXS analysis was conducted using an electron beam 
with accelerating voltage of $15-20 \mathrm{kV}$ where the specimen was mounted at the working distance of 9-12 mm. Aperture size was consistently adjusted to obtain an optimum signal count.

\section{4. $2 \mathrm{D}$ and $3 \mathrm{D}$ investigation of localised corrosion}

After removal of the corrosion products in the pickling stage, 3D topography of the sample surface was obtained by interference microscopy using a Veeco optical profiling system (RST Plus WYKO). The measurements were carried out in the vertical scanning interferometry (VSI) mode, where the vertical range was $0.5 \mathrm{~mm}$ with a resolution better than $10 \mathrm{~nm}$. A 10x objective was used which produced $457 \times 610 \mu \mathrm{m}^{2}$ field of view.

A Versa 3D DualBeam FIB microscope was employed to operate successive slicing and imaging on the exposed samples when the corrosion product was removed. The thickness of each slice was approximately $500 \mathrm{~nm}$. An ion beam current of $28 \mathrm{nA}$ at the accelerating voltage of $30.00 \mathrm{kV}$ was used during milling. Secondary electron (SE) in-situ imaging was performed at the accelerating voltage of $5.00 \mathrm{kV}$ and working distance of $10.0 \mathrm{~mm}$. Figure 1 depicts an illustration of the "slice and image", "3D reconstruction" and "post-preparation analysis" setups. Samples were tilted $7^{\circ}$ while milling, thus $45^{\circ}$ slices were prepared in each pass (look at Fig. 1). An electron image was taken and saved at the end of each run. The stack of slices that were prepared by means of FIB was compiled, aligned and processed by FIJI software (a distribution of open-source software ImageJ) [29] and a 3D illustration was created. After preparation by FIB, selected cross-sections were analysed in a regular SEM system (Fig. 1).

\section{Figure 1}




\section{Results}

\subsection{Gravimetry and corrosion products}

Tables II shows the average dry mass gain of AM50 and AZ91 after $672 \mathrm{~h}$ exposure at $22.00^{\circ} \mathrm{C}$ and $95.0 \% \mathrm{RH}$ with different amounts of added $\mathrm{NaCl}$. Figure 2 (a) depicts average metal loss as function of the amount of added $\mathrm{NaCl}$ in the absence and in the presence of $400 \mathrm{ppm}^{\mathrm{CO}}$. The results show that alloy AM50 exhibits 2.0-4.1 times higher corrosion rate than alloy AZ91. Also, both alloys corroded faster when $\mathrm{CO}_{2}$ was absent.

Figure 2 (b) shows XRD patterns for AM50 and AZ91 exposed for $672 \mathrm{~h}$ with $70 \mu \mathrm{g} / \mathrm{cm}^{2}$ added $\mathrm{NaCl}$, in the absence and in the presence of $400 \mathrm{ppm} \mathrm{CO}_{2}$. In the absence of $\mathrm{CO}_{2}$, brucite $\mathrm{Mg}(\mathrm{OH})_{2}$ was the dominant corrosion product together with small amounts of meixnerite $\mathrm{Mg}_{6} \mathrm{Al}_{2}(\mathrm{OH})_{18} \cdot 4.5 \mathrm{H}_{2} \mathrm{O}$. In the presence of $\mathrm{CO}_{2}$ Giorgiosite $\mathrm{Mg}_{5}\left(\mathrm{CO}_{3}\right)_{4}(\mathrm{OH})_{2} \cdot 5 \mathrm{H}_{2} \mathrm{O}$ and $\mathrm{Mg}_{5}\left(\mathrm{CO}_{3}\right)_{4}(\mathrm{OH})_{2} \cdot 8 \mathrm{H}_{2} \mathrm{O}$ were observed. Hydromagnesite, $\mathrm{Mg}_{5}\left(\mathrm{CO}_{3}\right)_{4}(\mathrm{OH})_{2} \cdot 4 \mathrm{H}_{2} \mathrm{O}$ which has been reported to form under similar conditions $[1,23,8]$ was not identified. As expected, the intensity of the $\beta$-phase $\left(\mathrm{Mg}_{17} \mathrm{Al}_{12}\right)$ peaks relative to the $\alpha$-Mg peaks was greater for $\mathrm{AZ91}$ compared to AM50.

\section{Table II and Figure 2}

\subsection{Alloy Microstructure}

Figure 3 shows the microstructure of alloys AM50 and AZ91 before exposure (polished and etched surface). The alloy microstructure had four constituents, including $\alpha-\mathrm{Mg}, \mathrm{Mg}_{17} \mathrm{Al}_{12}(\beta-$ phase), $\mathrm{Al}_{\mathrm{x}}(\mathrm{Mn}, \mathrm{Fe})_{\mathrm{y}}$ particles (wherein the ' $\mathrm{X}$ ' to "Y" ratio depends on the $\mathrm{Fe}$ and $\mathrm{Mn}$ concentrations in the alloy, such as $\left.\mathrm{Al}_{8}(\mathrm{Mn}, \mathrm{Fe})_{5}\right)$ and an $\mathrm{Al}$-rich segregation band, the $\beta$-phase being situated within the segregation band. As expected, alloy AZ91 exhibited a higher fraction of $\beta$-phase and a slightly higher Al content in the $\alpha$-Mg grains than alloy AM50 (see Table III). Also, the $\beta$ intermetallics were finer in alloy AM50 than in alloy AZ91. In addition, the $\beta$-phase was discontinuous in AM50 while it formed a 'semi-continuous' network in AZ91 (see Fig. 3). Table III presents the average values for the area fraction of $\beta$-phase and the average concentration of $\mathrm{Al}$ in the center of the $\alpha-\mathrm{Mg}$ grains.

\section{Table III \& Figure 3}

\subsection{Corrosion product morphology in the presence and absence of $\mathrm{CO}_{2}$}

Inspection of the exposed samples in the SEM showed that corrosion was more pronounced for alloy AM50 than for AZ91 both in the presence and absence of $\mathrm{CO}_{2}$, in accordance with the corrosion rate measurements. The SE and backscatter electron (BSE) micrographs in Fig. 4 show typical surface morphologies after $672 \mathrm{~h}$ exposure of the alloys in the presence of 70 $\mu \mathrm{g} / \mathrm{cm}^{2} \mathrm{NaCl}$ at $22^{\circ} \mathrm{C}$ and $95 \% \mathrm{RH}$. The inserts in Fig.5 shows the corroded surface at higher magnification. An inspection of Fig. 4 indicates that corrosion was more severe in the absence of $\mathrm{CO}_{2}$, in accordance with the mass loss results (see Table II and Fig. 2 (a)). Both alloys showed 
a greater tendency for localised corrosion in the absence of $\mathrm{CO}_{2}$. Thus, in the presence of $\mathrm{CO}_{2}$ corrosion products covered the entire surface while in the absence of $\mathrm{CO}_{2}$, parts of the surface were little affected by corrosion while other areas were covered by large amounts of corrosion products (compare Figs. 4 (a), (b) with 400 ppm $\mathrm{CO}_{2}$, and Figs. 4 (c), (d) without $\mathrm{CO}_{2}$ ). The heavily corroded areas formed in the absence of $\mathrm{CO}_{2}$ tended to be interconnected, see Fig. 4 (c), (d). The connections are indicated by yellow dashed lines in Fig. 5 (c) and d. Regions 5 and 6 in Figs. 4 (c) and (d) exemplify unconnected corroded regions. After exposure in the presence of $\mathrm{CO}_{2}$, both alloys exhibited spherical agglomerations of corrosion products, indicated by arrows in the inserts. Unreacted $\mathrm{NaCl}$ was occasionally observed on alloy AZ91 after exposure in the presence of $\mathrm{CO}_{2}$ (Fig. 4 (b)).

\section{Figure 4}

\subsection{EDXS analysis of corroded samples}

This section describes EDXS analyses of exposed alloy AM50. The AM50 samples were selected for imaging because the corrosion attack was more severe for that material. However, the corresponding images for alloy AZ91 were similar with respect to the distribution of elements on the surface. Figure 5 shows EDXS elemental maps of the corroded surface of alloy AM50 (400 ppm CO $2,70 \mu \mathrm{g} / \mathrm{cm}^{2} \mathrm{NaCl}, 672 \mathrm{~h}, 22^{\circ} \mathrm{C}, 95 \% \mathrm{RH}$ ). The overlap of the $\mathrm{Na}$ and $\mathrm{Cl}$ maps show the presence of $\mathrm{NaCl}$ on the sample surface. The elemental maps show areas in the vicinity of the salt particle where chlorine was present and no Na was detected. EDXS point analysis at this area (indicated by a cross in Fig. 5) revealed that it was dominated by $\mathrm{O}, \mathrm{Mg}$, $\mathrm{C}$, and $\mathrm{Cl}$, implying that $\mathrm{Cl}$ was associated to magnesium.

\section{Figure 5}

Figure 6 demonstrates a corresponding EDXS elemental mapping of alloy AM50 exposed in the absence of $\mathrm{CO}_{2}$. In this case there was no indication of $\mathrm{NaCl}$, the $\mathrm{Cl}$ and $\mathrm{Na}$ maps showing little overlap. Thus, $\mathrm{Na}$ was concentrated on the relatively uncorroded metal surface between the corrosion product accumulations where there was little evidence for $\mathrm{Cl}$. Sodium tended to be concentrated in areas with high Al signal, corresponding to segregation bands rich in $\beta$-phase particles. Chlorine was mainly detected on the periphery of the large corrosion product accumulations and in relatively small corrosion product accumulations. An EDXS point analysis of a small Cl-rich surface feature (indicated by a cross in Fig. 5) showed that it consisted of $\mathrm{O}, \mathrm{Mg}, \mathrm{Cl}$ and $\mathrm{C}$, being similar to the point analysis in Fig. 5 and indicating the presence of magnesium chloride. The carbon detected in the point analysis in Fig. 6 is suggested to be contamination due to handling of the sample in the laboratory air.

\section{Figure 6}

Figure 7 shows an EDXS map of another area of alloy AM50 after exposure in the absence of $\mathrm{CO}_{2}$. The main difference compared to Fig. 6 is a higher frequency of intermetallics (i.e. $\beta$ - and especially $\mathrm{Al}_{\mathrm{x}}(\mathrm{Mn}, \mathrm{Fe})_{\mathrm{y}}$ particles) as shown by the $\mathrm{Al}$ and $\mathrm{Mn}$ maps. It may be noted that Fig. 7 shows a strong tendency for $\mathrm{Na}$ to be associated with the Mn-containing intermetallic particles, i.e. $\mathrm{Al}_{8}(\mathrm{Mn}, \mathrm{Fe})_{5}$, which is also known as $\eta$ in the literature. In contrast, there is little 
overlap between the Al-rich areas with no Mn ( $\beta$-phase) and Na maps. An area analysis was carried out at the large $\mathrm{Al}_{\mathrm{x}}(\mathrm{Mn}, \mathrm{Fe})_{\mathrm{y}}$-phase particle in the boxed area in Fig. 7. The analysis indicates that sodium was concentrated at the $\mathrm{Al}_{\mathrm{x}}(\mathrm{Mn}, \mathrm{Fe})_{\mathrm{y}}$-phase particle.

\section{Figure 7}

\subsection{Characterisation of localised corrosion}

As shown above (see Fig. 4) the NaCl-induced corrosion of the two alloys was localised both in the presence and in the absence of $\mathrm{CO}_{2}$. However, corrosion was more strongly localised in the absence of $\mathrm{CO}_{2}$. In both environments, localised corrosion was developed. In order to investigate the morphology of the affected areas, 3D topographical profiles were obtained from both materials after removing the corrosion product by pickling. Figure 8 shows the two alloys after exposure in the presence of $400 \mathrm{ppm}$ of $\mathrm{CO}_{2}$ and Fig. 9 shows the materials after exposure in the absence of $\mathrm{CO}_{2}$. Furthermore, 2D profiles (see the lines parallel to the $\mathrm{X}$ and $\mathrm{Y}$ directions on each sample) are shown in the respective figures. On each sample a region of interest (ROI) was selected (indicated in the figures) showing a typical area affected by localised corrosion. On the 2D profile the ROI is the area between the red and blue lines (see Fig. 8 and 9).

The situation in the presence of $\mathrm{CO}_{2}$ is illustrated in Fig. 8, showing sites of localised corrosion with different sizes on both alloys. The distance between these individual sites of dissolution was similar to the distance between the corrosion product accumulations seen in Fig. 4. Optical profilometry measurements showed that the maximum depth of locally affected area for AM50 alloy $(58 \mu \mathrm{m})$ was about twice as great than for AZ91 alloy $(31 \mu \mathrm{m})$. Accordingly, the ROI measurements in Fig. 8 show that the dissolution sites formed on alloy AM50 were on average deeper than on alloy AZ91.

The situation after exposure in the absence of $\mathrm{CO}_{2}$ is illustrated in Fig. 9. The 2D and 3D imaging revealed that in this environment both alloys formed were deep and shallow locally affected regions. Figures 9 (a) and (c) show examples of the deep regions while Figs. 9 (b) and (d) demonstrate relatively shallow sites of dissolution on alloy AM50 and on AZ91. The deep areas were interconnected, forming a network below the alloy surface. The 3D profiles show the absence of individual localised corrosion sites in the vicinity of the network of deep areas of dissolution (see Figs. 9 (a) and (c)). The shallow dissolution sites formed in the absence of $\mathrm{CO}_{2}$ have a distribution which is similar to that observed in the presence of $\mathrm{CO}_{2}$. Both classes of localised corrosion were deeper for alloy AM50 than for alloy AZ91.

\section{Figures 8 and 9}

To complement the results from the optical profilometry, representative regions localised corrosion were selected and studied by consecutive steps of FIB cross-sectional milling-SE imaging. This procedure provided us with the opportunity to study the connectivity of locally effected areas with $500 \mathrm{~nm}$ increments (i.e. the thickness of each slice) in the selected area. A stack of images was compiled corresponding to the investigated volume. 
Figure 10 shows selected cross-sections that were cropped from the compiled volumes. Figure 10, also includes the plan view micrograph of the same volume and shows the selected area. The sites of localised dissolution formed in the absence of $\mathrm{CO}_{2}$ were connected deep in the bulk (see Fig. 10 (a) and (b)) for both alloys. In contrast, the localised corrosion sites formed in the presence of $400 \mathrm{ppm} \mathrm{CO}$ remained unconnected (see Fig. 10 (c) and (d)).

\section{Figure 10}

\subsection{Correlation between localised corrosion and the distribution of intermetallics}

Figure 11 shows the SEM-BSE cross-sectional micrographs for the alloy AZ91 after removal of the corrosion products formed upon exposure to humid air $\left(70 \mu \mathrm{g} / \mathrm{cm}^{2} \mathrm{NaCl}\right)$ in the presence and absence of $\mathrm{CO}_{2}$. Both images (i.e. Fig. 11 (a) and (b)) show the presence of $\beta$ - and $\mathrm{Al}_{\mathrm{x}}(\mathrm{Mn}$, $\mathrm{Fe})_{\mathrm{y}}$-phase in the vicinity of the locally dissolved sites under the alloy surface. In the alloys under investigation herein, the growth of the localised corrosion sites could not effectively be ceased as the they reached at the $\beta$ particles and as described in the literature [12]. This can be explained by the 3D nature of the alloy being corroded (or the notion that $\beta$ phase can never form a 3D network of particles in the alloy). The correlation of localised corrosion and $\beta$-phase was even less clear in the case of the AM50 alloy due to the small size of the $\beta$-phase particles relative to the size of the localised corrosion sites.

Figure 11 


\section{Discussion}

\section{1. $\mathrm{NaCl}$ induced atmospheric corrosion of $\mathrm{Mg}$ - $\mathrm{Al}$ alloys}

As a result of hydrogen evolution and the migration of $\mathrm{Na}^{+}(\mathrm{aq})$, the cathodic regions become alkaline. In contrast, chloride accumulates at the anodic sites, the resulting $\mathrm{MgCl}_{2}$ (aq) solution being slightly acidic. Thus, a $\mathrm{pH}$ gradient develops between anodic and cathodic areas. In the absence of these Faradaic processes, the $\mathrm{pH}$ of water in equilibrium with brucite is about 10.0 [30]. Because of the relatively low $\mathrm{pH}$ of the anolyte and the presence of chloride, the semiprotective film does not easily heal. Thus, corrosion in $\mathrm{NaCl}$ (aq) solution is cathodically controlled and very high corrosion rates are observed for materials containing large amounts of second phase particles and noble inclusions that can act as cathodes [31, 32].

The semi-protective corrosion films formed on $\mathrm{Mg}$ - $\mathrm{Al}$ alloys are reported to contain $\mathrm{Al}^{3+}$ which is expected to modify corrosion behavior [1, 33-35]. Thus, at neutral $\mathrm{pH}, \mathrm{MgO}$ and $\mathrm{Mg}(\mathrm{OH})_{2}$ are soluble while alumina $\left(\mathrm{Al}(\mathrm{OH})_{3}\right.$ or $\left.\mathrm{Al}_{2} \mathrm{O}_{3}\right)$ is insoluble. Therefore, it is expected that the stability of the oxide/hydroxide film at neutral $\mathrm{pH}$ (in the anodic areas) is improved somewhat by alloying with aluminum. However, the extensive localised corrosion observed on the two $\mathrm{Mg}-\mathrm{Al}$ alloys studied in this work shows that the alumina-containing films formed on the $\alpha$ $\mathrm{Mg}$ matrix of $\mathrm{Mg}-\mathrm{Al}$ alloys are quite susceptible to localised corrosion in $\mathrm{NaCl}(\mathrm{aq})$ solution. This is in accordance with the well-known fact that aluminum also suffers localised corrosion (pitting) in $\mathrm{NaCl}$ (aq) [36]. In alkaline solutions (at high pH), e.g., on the $\mathrm{Mg}(\mathrm{OH})_{2}$ surface and especially in the cathodic areas, alumina is soluble forming aluminate ions ( $\mathrm{Al}(\mathrm{OH})_{4}^{-}(\mathrm{aq})$ ). Consequently, meixnerite $\left(\mathrm{Mg}_{6} \mathrm{Al}_{2}(\mathrm{OH})_{18} \cdot 4.5 \mathrm{H}_{2} \mathrm{O}\right)$ (also reported as $\mathrm{Mg}_{6} \mathrm{Al}_{2}(\mathrm{OH})_{18} \cdot 4 \mathrm{H}_{2} \mathrm{O}$ [37]) formed in the absence of $\mathrm{CO}_{2}$. Meixnerite is a layered double hydroxide ( $\mathrm{LDH}$ ) compound and can be precipitated from alkaline solutions containing both magnesium and aluminium. The lack of evidence for meixnerite after exposure to $400 \mathrm{ppm} \mathrm{CO}_{2}$ may be due to its reaction with $\mathrm{CO}_{2}$ to form poorly crystalline aluminium magnesium hydroxy carbonate LDHs. Moreover, the $\mathrm{pH}$ decrease caused by $\mathrm{CO}_{2}$ will diminish alumina solubility in the surface electrolyte. It is suggested that the decreased tendency for alumina to dissolve in the surface electrolyte because of neutralisation by $\mathrm{CO}_{2}$ adds to the corrosion inhibitive effect of $\mathrm{CO}_{2}$ towards $\mathrm{Mg}-\mathrm{Al}$ alloys.

The presence of strong $\mathrm{pH}$ gradients on the surface is illustrated by the EDXS map of Na in Fig. 6 (alloy AM50 exposed in the absence of $\mathrm{CO}_{2}$ ) showing that $\mathrm{Na}$ is present between two heavily corroded regions. The two regions correspond to anodic areas while $\mathrm{Na}$ is concentrated at the cathodic sites. This suggests the presence of large corrosion cells (several tenths of micrometer) on the surface. Moreover, the Na map in Fig. 7; i.e. alloy AM50 in the absence of $\mathrm{CO}_{2}$, shows that $\mathrm{Na}$ is concentrated at the $\mathrm{Mn}$-containing second phase particles (i.e. at the $\mathrm{Al}_{\mathrm{x}}(\mathrm{Mn}, \mathrm{Fe})_{\mathrm{y}}$ particles). According to Jönsson et al. [38] $\mathrm{Al}_{\mathrm{x}}(\mathrm{Mn}, \mathrm{Fe})_{\mathrm{y}}$ (designated as $\eta$, in that paper)-phase particles have higher open-circuit corrosion potential than $\beta$ and $\alpha$-Mg phase. In addition, insitu Volta potential measurements by scanning Kelvin probe force microscopy (SKPFM) revealed the following sequence for the relative Volta potentials in alloy $\mathrm{AZ91:} \mathrm{Al}_{\mathrm{x}}(\mathrm{Mn}, \mathrm{Fe})_{\mathrm{y}}>$ $\beta \sim$ segregation band $>\alpha-\mathrm{Mg}$ [38]. Thus, $\mathrm{Al}_{\mathrm{x}}(\mathrm{Mn}, \mathrm{Fe})_{\mathrm{y}}$-phase, $\beta$-phase and the segregation band were all cathodic towards the $\alpha-\mathrm{Mg}$ grains. Nevertheless, Jönsson et al. claimed [38] that the $\mathrm{Al}_{\mathrm{x}}(\mathrm{Mn}, \mathrm{Fe})_{\mathrm{y}}$-phase was not active in the initiation of corrosion since it was embedded in the $\beta$ - 
phase, far from the $\alpha$-phase. However, the cathodic activity of $\mathrm{Al}_{\mathrm{x}}(\mathrm{Mn}, \mathrm{Fe})_{\mathrm{y}}$-phase particles revealed in the present work is in line with a recent paper by Danaie et al. [39], and Esmaily et al. [35]. Moreover, Arrabal et al. [40] have shown that corrosion of Mg-Al alloys occurred at the interface between $\beta$ - and $\mathrm{Al}_{\mathrm{x}}(\mathrm{Mn}, \mathrm{Fe})_{\mathrm{y}}$ particles and the $\alpha-\mathrm{Mg}$ matrix. Hence, the results presented in this paper confirms the notion that both $\beta$ and $\mathrm{Al}_{\mathrm{x}}(\mathrm{Mn}, \mathrm{Fe})_{\mathrm{y}}$ can act as cathodes in $\mathrm{Mg}-\mathrm{Al}$ alloys, developing micro-galvanic cells.

The excellent correlation between $\mathrm{Mn}$ and $\mathrm{Na}$ in Fig. 7 implies that in that case, $\mathrm{Al}_{\mathrm{x}}(\mathrm{Mn}, \mathrm{Fe})_{\mathrm{y}}$ phase particles are more active cathodes than the $\beta$-particles. This can be associated with the high $\mathrm{pH}$ in the cathodic areas in the absence of $\mathrm{CO}_{2}$. As mentioned above, alumina dissolves at high $\mathrm{pH}$. Thus, while the $\beta$-phase is expected to be covered by an insulating $\mathrm{MgO} / \mathrm{Mg}(\mathrm{OH})_{2}$ layer at high $\mathrm{pH}$, the $\mathrm{Al}_{\mathrm{x}}(\mathrm{Mn}, \mathrm{Fe})_{\mathrm{y}}$-phase particles are expected to be covered by oxides and hydroxides of manganese. Among these, only $\mathrm{Mn}(\mathrm{OH})_{2}$ is an electronic insulator while $\mathrm{MnO}$, $\mathrm{Mn}_{3} \mathrm{O}_{4}$ and $\mathrm{MnOOH}$ are semiconductors. Accordingly, Danaie et al. reported that after $96 \mathrm{~h}$ exposure in 1.6 wt.\% $\mathrm{NaCl}$ solution, $\mathrm{Mn}_{3} \mathrm{O}_{4}$ formed on the $\mathrm{Al}_{\mathrm{x}}(\mathrm{Mn}, \mathrm{Fe})_{\mathrm{y}}$-phase as a result of high local alkalinity and preferential dissolution of $\mathrm{Al}$ [39]. Thus, it is suggested that the relatively high cathodic activity of $\mathrm{Al}_{\mathrm{x}}(\mathrm{Mn}, \mathrm{Fe})_{\mathrm{y}}$-phase particles in the absence of $\mathrm{CO}_{2}$ is due to the formation of an electronically conducting surface film on the particles, alumina dissolving as aluminate ions due to the high $\mathrm{pH}$. This also implies that, because the alumina component in the oxide film becomes less soluble with decreasing $\mathrm{pH}$, the cathodic activity of the $\mathrm{Al}_{\mathrm{x}}(\mathrm{Mn}$, $\mathrm{Fe})_{\mathrm{y}}$-phase particles is lower in $\mathrm{CO}_{2}$ containing air.

Surface $\mathrm{pH}$ also has important implications for the distribution of electrolyte. Thus, investigating the $\mathrm{NaCl}$-induced atmospheric corrosion of $\mathrm{Cu}$, Chen et al. reported [41] that $\mathrm{NaCl}$ (aq) droplets formed on the sample at $80 \% \mathrm{RH}$ in air tended to spread over the sample surface when the concentration of $\mathrm{CO}_{2}$ was $<5 \mathrm{ppm}$. In contrast, there was little spreading of the droplets at ambient levels of $\mathrm{CO}_{2}$. The effect was explained by the cathodic reaction causing a high $\mathrm{pH}$ in the periphery of the droplets in the absence of $\mathrm{CO}_{2}$. It was argued that the high $\mathrm{pH}$ resulted in a negative surface charge, decreasing the surface tension of the oxide-electrolyte interface and favoring wetting of the surface. In the present study Figs. 4 (a) and (b) present closely spaced spherical corrosion product accumulations on the surface of alloys AM50 and AZ91 alloys after exposure in the presence of $400 \mathrm{ppm} \mathrm{CO}_{2}$. It is argued that the corrosion product distribution mimics the distribution of the $\mathrm{NaCl}$ (aq) droplets formed when the samples were introduced into the sample chamber, at the start of the exposure. In contrast, after the $\mathrm{CO}_{2}-$ free exposures of both alloys there was extensive coalescence of $\mathrm{NaCl}$ (aq) droplets and correspondingly extended corrosion cells were observed, resulting in severe localised corrosion.

\subsection{Localised corrosion: formation and connectivity}

It was already noted that while the areas affected by localised corrosion were evenly distributed in the presence of $\mathrm{CO}_{2}$, severe localised corrosion developed only a small part of the surface in the absence of $\mathrm{CO}_{2}$, large areas remaining relatively uncorroded (see Figs. 5). These observations were corroborated by $3 \mathrm{D}$ characterisation after corrosion product removal. Thus, a relatively shallow and isolated sites of localised corrosion formed in the presence of $\mathrm{CO}_{2}$ is 
seen in Fig. 8. In contrast, two distinctive groups of dissolution regions were observed after corrosion in the absence of $\mathrm{CO}_{2}$ (see Fig. 9), namely (a) very deep connected sites of localised dissolution, and (b) quite shallow isolated dissolution areas. The deep ones, shown in Figs. 10 (a) and (c) and the 3D cross-sectional views are shown in Figs. 11 (a) and (b), correspond to the severely affected areas in Figs. 5 (c) and (d). The images show that individual localised sites of metal loss are connected, forming a network below the surface.

The present results regarding the morphology of localised corrosion indicate that in the presence of $\mathrm{CO}_{2}$, the corrosion cells on the surface are relatively small (in the range 2-20 $\mu \mathrm{m}$, considering the distribution of the microstructural constituents) and have a single anodic site situated in the $\alpha-\mathrm{Mg}$ matrix. In contrast, the corrosion cells formed in the absence of $\mathrm{CO}_{2}$ are much larger and exhibit multiple, closely spaced anodic sites that tend to interconnect. The occurrence of larger corrosion cells in the absence of $\mathrm{CO}_{2}$ is attributed partly to the enhanced wetting of the surface and the resulting drop coalescence mentioned above, and partly to the $\mathrm{NaOH}$ (aq) catholyte formed in the absence of $\mathrm{CO}_{2}$ providing greater surface conductivity compared to the $\mathrm{Na}_{2} \mathrm{CO}_{3}$ (aq) $/ \mathrm{NaHCO}_{3}(\mathrm{aq})$ solution formed in the presence of $\mathrm{CO}_{2}$. It is argued that the large corrosion cells include many cathodic sites $\left(\mathrm{Al}_{\mathrm{x}}(\mathrm{Mn}, \mathrm{Fe})_{\mathrm{y}}\right.$ - and $\beta$-phase particles). Therefore and because of the absence of $\mathrm{CO}_{2}$, most of the alloy surface within the cell experiences high $\mathrm{pH}$, stabilising the $\mathrm{MgO} / \mathrm{Mg}(\mathrm{OH})_{2}$ semi-protective film. In this scenario, the sites of localised dissolution in the $\alpha-\mathrm{Mg}$ matrix are expected to become strongly polarised anodically, in accordance with the rapid growth of locally affected areas observed.

In order to explain the formation of multiple and interconnected locally affected areas, it is suggested that each corrosion cell initially contains only one localised damage. With time, the corrosion cell increases in size as described above, encompassing a growing number of cathodic sites. This will cause the first region of dissolution to become increasingly polarised in the anodic direction, causing it to grow faster. However, with time the area growth will saturate or slow down because of solid precipitates (brucite + meixnerite) blocking the mouth of dissolution sites. This will cause the anodic polarisation of the $\alpha-\mathrm{Mg}$ matrix surface in the vicinity of the initial localised damage to increase, resulting in the formation of a new locally corroded area. The relatively low $\mathrm{pH}$ and the chloride ions associated with the initial dissolution site are expected to make the semi-protective film in the vicinity of the original locally affected area more sensitive to attack, contributing to clustering of dissolution sites.

In the presence of $\mathrm{CO}_{2}$, several of the mechanism suggested above to cause clustering of the localised corrosion are absent. Thus, the $\mathrm{NaCl}$ (aq) droplets on the surface do not coalesce so that the corrosion cells do not grow in size and neutralisation by $\mathrm{CO}_{2}$ is expected to decrease surface conductivity, further restricting the size of the corrosion cells and corrosion current. Furthermore, the decreased $\mathrm{pH}$ on the surface is expected to destabilise the $\mathrm{MgO} / \mathrm{Mg}(\mathrm{OH})_{2}$ surface film, resulting in an easier initiation of localised corrosion contributing to the occurrence of many small corrosion cells. 


\section{Conclusions}

Using a combined 2D and 3D investigation, the localised corrosion susceptibility of semi-solid cast alloys AM50 and AZ91 was studied in the presence of humid air (95\% RH), $\mathrm{CO}_{2}$ (carefully controlled to be either 0 or $400 \mathrm{ppm}$ ) and $14-70 \mu \mathrm{g} / \mathrm{cm}^{2} \mathrm{NaCl}$. The following conclusions can be drawn as a result of the present study:

- The simple 3D characterisation conducted using the focus ion beam milling (FIB) technique was proved to be useful in evaluating the corrosion microstructure of the alloys studied. The 3D investigation (which was performed the three steps: using slice/image, $3 \mathrm{D}$ reconstruction, and post-preparation analysis) showed the formation of deep and meandering sites of localised dissolution within the bulk.

- The presence of $400 \mathrm{ppm} \mathrm{CO}_{2}$ in humid air (95\% RH) inhibited atmospheric corrosion and strongly affected the corrosion morphology of the alloys. After exposure in the presence of $400 \mathrm{ppm} \mathrm{CO}_{2}$ most of the surface was covered by corrosion products dominated by magnesium hydroxy carbonates. In the absence of $\mathrm{CO}_{2}$, part of the surface was heavily corroded while large areas were seemingly unaffected by corrosion (which was explained by the formation of extended corrosion cells). The corrosion products were mainly brucite $\left(\mathrm{Mg}(\mathrm{OH})_{2}\right)$ and the $\mathrm{LDH}$ compound meixnerite $\left(\mathrm{Mg}_{6} \mathrm{Al}_{2}(\mathrm{OH})_{18} \cdot 4.5 \mathrm{H}_{2} \mathrm{O}\right)$.

- In the presence of $400 \mathrm{ppm} \mathrm{CO}_{2}$, the areas of localised corrosion were evenly distributed over the surface and relatively shallow. These affected the areas covered by $\mathrm{NaCl}$ (aq) droplets formed when the exposure started. In the absence of $\mathrm{CO}_{2}$ sites of localised corrosion were deeper and tended to cluster. The clustered areas interconnected, forming networks below the surface of the alloy.

- In the absence of $\mathrm{CO}_{2}$, the $\mathrm{Al}_{x}(\mathrm{Mn}, \mathrm{Fe})_{y}$-phase precipitates were cathodically more active than the $\beta$-phase particles. This is explained by the high $\mathrm{pH}$ electrolyte which dissolves alumina, leaving behind a $\mathrm{Mn}_{\mathrm{x}} \mathrm{O}_{\mathrm{y}} / \mathrm{Mn}(\mathrm{OH})_{2}$ surface film on the $\mathrm{Al}_{\mathrm{x}}(\mathrm{Mn}, \mathrm{Fe})_{\mathrm{y}}$-phase particles which is electronically more conducting than the alumina-dominated film present at lower $\mathrm{pH}$.

- In the absence of $\mathrm{CO}_{2}$, the $\mathrm{NaCl}$ (aq) droplets coalesce, due to enhanced wetting of the surface, resulting in the formation of comparatively large corrosion cells. The clustering of dissolution sites in the absence of $\mathrm{CO}_{2}$ is attributed to the growth of the corrosion cells, encompassing a growing number of cathodic sites. Due to the resulting increased anodic polarisation of the area in the vicinity of the original dissolution site, new regions of dissolution tend to initiate.

- The formation of a protective layer of magnesium hydroxy carbonate and the greater stability of the alumina component in the surface film formed on $\alpha-\mathrm{Mg}$ (caused by the lowering of $\mathrm{pH}$ ) contributes to the corrosion inhibitive effect of $\mathrm{CO}_{2}$. 
The authors would like to express their thanks to the Swedish Foundation for Strategic Research (SSF) for funding this project. Dr. Rikard Ylmén is acknowledged for his assistance in the FTIR measurements. ME thanks the Swedish Research Council and the Royal Swedish Academy of Engineering Sciences for the financial support. 


\section{References}

1. M. Esmaily, J.E. Svensson, S. Fajardo, N. Birbilis, G.S. Frankel, S. Virtanen, R. Arrabal, S. Thomas, L.G. Johansson, Prog. Mater. Sci. 89 (2017): p. 92-193.

2. Y. Kojima, Mater. Sci. Forum 350-351 (2000): p. 3-18.

3. R. Lindstrom, L.G. Johansson, G.E. Thompson, J.E. Svensson, Corros. Sci. 46 (2004): p. 1141-1158.

4. G. Williams, H. Llwyd Dafydd, R. Grace, Electrochim. Acta 109 (2013): p. 489-501

5. M. Esmaily, M. Shahabi-Navid, J.E. Svensson, M. Halvarsson, L. Nyborg, Y. Cao, L.G. Johansson, Corros. Sci. 90 (2015): p. 420-433.

6. M. Esmaily, D.B. Blücher, R.W. Lindström, J.E. Svensson, L.G. Johansson, J. Electrochem. Soc. 162 (2015): p. C260-C269.

7. M. Esmaily, J.E. Svensson, L.G. Johansson, In: Solanki K., Orlov D., Singh A., Neelameggham N. (eds) Magnesium Technology 2017. The Minerals, Metals \& Materials Series. Springer Magnesium Technology (2017): p. 397-403.

8. M. Shahabi-Navid, M. Esmaily, J.E. Svensson, M. Halvarsson, L. Nyborg, Y. Cao, L.G. Johansson, J. Electrochem. Soc. 161 (2014): p. C277-C287.

9. W. Xu, N. Birbilis, G. Sha, Y. Wang, J.E. Daniels, Y. Xiao, M. Ferry, Nat. Mater. 14 (2015): p. 1229 1235.

10. Z. Hu, R.L. Liu, S.K. Kairy, X. Li, H. Yan, N. Birbilis, Corros. Sci. 149 (2019): p. 144-152.

11. R. Tunold, H. Holtan, M. B. Hägg Berge, A. Lasson, R. Steen-Hansen, Corros. Sci. 17 (1977): p. 353-365.

12. A. Pardo, M.C. Merino, A.E. Coy, F. Viejo, R. Arrabal, S. FeliúJr, Electrochim. Acta 53 (2008): p. 7890-7902.

13. S.J. Splinter, N.S. Mcintyre, Surf. Sci. 314 (1994): p. 157-171.

14. Y.M. Yan, A. Maltseva, P. Zhou, X.J. Li, Z.R. Zeng, O. Gharbi, K. Ogle, M. La Haye, M. Vaudescal, M. Esmaily, N. Birbilis, P. Volovitch, Corros. Sci.164 (2020): 108342.

15. W.M. Chan, F.T. Cheng, L.K. Leung, R.J. Horylev, T.M. Yue, Corros. Rev. 16 (1998): p. 43-52.

16. M. Esmaily, N. Mortazavi, J.E. Svensson, L.G. Johansson, M. Halvarsson, Ultramicro, 153 (2015), p. 45-54.

17. M. Esmaily, N. Mortazavi, J.E. Svensson, M. Halvarsson, A.E.W. Jarfors, M. Wessén, R. Arrabal, L.G. Johansson, Mater. Chem. Phys. 180 (2016): p. 29-37.

18. M. Esmaily, Z. Zeng, A.N. Mortazavi, A. Gullino, S. Choudhary, T. Derra, F. Benn, F. D'Elia, M. Müther, S. Thomas, A. Huang, A. Allanore, A. Kopp, N. Birbilis, Addit. Manuf. 35 (2020): 101321.

19. X. Zhou, C. Luo, T. Hashimoto, A.E. Hughes, G.E. Thompson, Corros. Sci. 58 (2012): p. 299-306.

20. T. Hashimoto, G.E. Thompson, X. Zhou, P.J. Withers, Ultramicro. 163 (2016): p. 6-18.

21. N. Mortazavi, C. Geers, M. Esmaily, V. Babic, M. Sattari, K. Lindgren, P. Malmberg, B. Jönsson, M. Halvarsson, J.E. Svensson, I. Panas, L.G. Johansson, Nat. Mater. 17 (2018) p. 610-617. 
22. H.M. Krebs, A. Chirazi, L. Lechner, J. Gelb, X. Zhou, G.E. Thompson, P.J. Withers, Frontiers in Materials Processing, Applications, Research and Technology: Select Proceedings of FiMPART, (2018) p. $165-177$.

23. M.C. Flemings, R.G. Riek, K.P. Young, Mater. Sci. Eng. 25 (1976): p. 103-117.

24. Esmaily, M. Shahabi-Navid, N. Mortazavi, J.E. Svensson, M. Halvarsson, M. Wessén, A.E.W. Jarfors, L.G. Johansson, Mater. Charac. 95 (2014): p. 50-64.

25. M. Esmaily, N. Mortazavi, J.E. Svensson, M. Halvarsson, D.B. Blücher, A.E.W. Jarfors, M. Wessén, L.G. Johansson, 162 (2015): J. Electrochem. Soc. p. C311-C321.

26. M. Esmaily, N. Mortazavi, M. Shahabi-Navid, J.E. Svensson, M. Halvarsson, L. Nyborg, M. Wessén, A.E.W. Jarfors, L.G. Johansson, J. Electrochem. Soc. 162 (2015): p. C85-C95.

27. M. Östklint, M. Wessén, A.E.W. Jarfors, Int. J. Cast Metal Res. 28 (2013): p. 65-71.

28. D.B. Blucher, J.E. Svensson, L.G. Johansson, Corros. Sci. 48 (2006): p. 1848-1866.

29. J. Schindelin, I. Arganda-Carreras, E. Frise, V. Kaynig, M. Longair, T. Pietzsch, S. Preibisch, C. Rueden, S. Saalfeld, B. Schmid, J.Y. Tinevez, D.J. White, V. Hartenstein, K. Eliceiri, P. Tomancak, A. Cardona, Nat. Methods 9 (2012): p. 676-682.

30. Y.L. Xiong, A.S. Lord, J. Appl. Geochem. 23 (2008): p. 1634-1659.

31. W.S. Loose, Corrosion and Protection of Magnesium. Materials Park, OH: ASM International (1946): p. 173-260.

32. Z.X. Qiao, Z. Shi, N. Hort, N. Abidin, A. Atrens, Corros. Sci. 61 (2012): p. 185-207.

33. J.H. Nordlien, K. NişancioĞu, S. Ono, N. Masuko, J. Electrochem. Soc. 143 (1996): p. 2564-2572.

34. K.A. Unocic, H.H. Elsentriecy, P.M. Brady, H.M. Meyer III, G.L. Song, M. Fayek, R.A. Meisner, B. Davis, J. Electrochem. Soc. 161 (2014): C302-C311.

35. M. Esmaily, D.B. Blücher, J.E. Svensson, M. Halvarsson, L.G. Johansson, Scrip. Mater. 115 (2016): p. 91-95.

36. T. Hagyard, J.R. Santhiapillai, J. Appl. Chem. 9 (1959): p. 323-330.

37. G. Mascolo, O. Marino, Mineral. Mag. 43 (1980): p. 619-621.

38. M. Jonsson, D. Thierry, N. LeBozec, Corros. Sci. 48 (2006): p. 1193-1208.

39. M. Danaie, R.M. Asmussen, P. Jakupi, D.W. Shoesmith, G.A.Botton, Corros. Sci. 83 (2014): p. 299 309.

40. R. Arrabal, A. Pardo, M.C. Merino, S. Merino, M. Mohedano, P. Casajús, Mater. Corros. 62 (2011) 326-334.

41. Z.Y. Chen, D. Persson, A. Nazarov, S. Zakipour, D. Thierry, C. Leygraf, J. Electrochem. Soc. 152 (2005) B342-B351. 


\section{Figures}

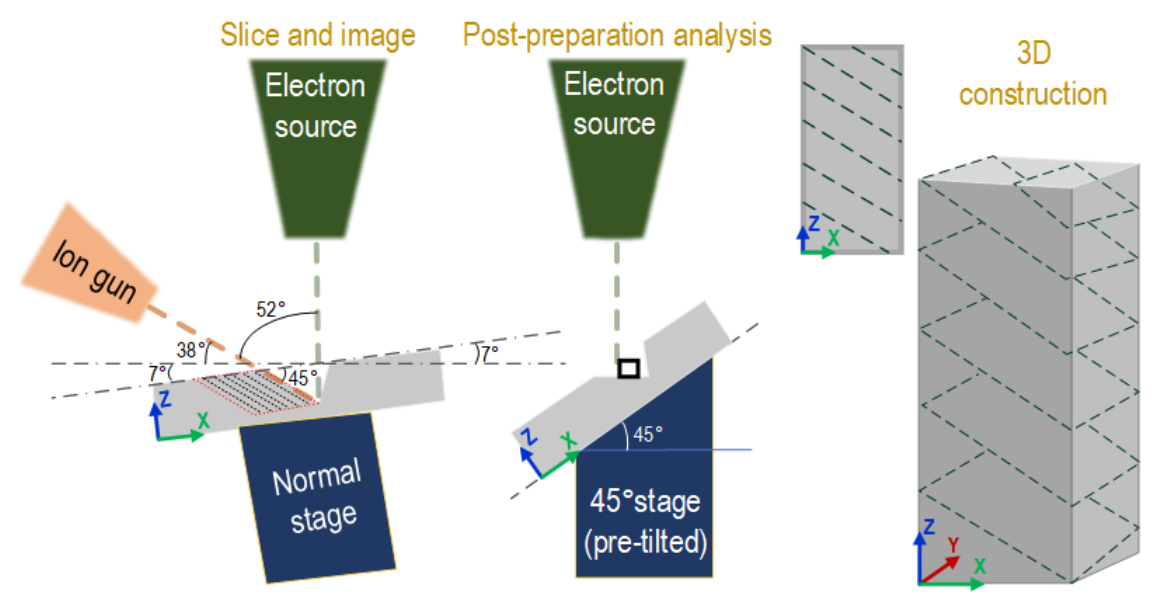

Fig. 1. Illustration of FIB milling showing the "slice and image", "3D reconstruction" and "post-preparation analysis" set-ups.
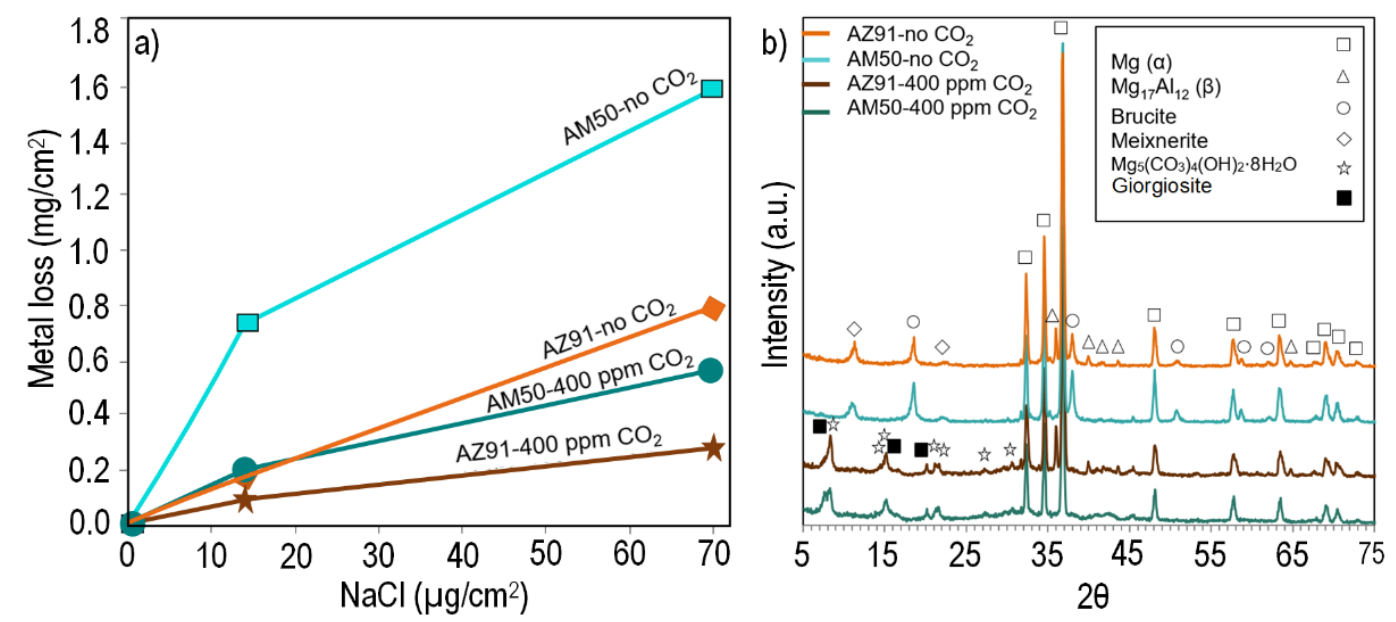

Fig. 2. (a) Metal loss of AZ91 and AM50 in the presence of different amounts of $\mathrm{NaCl}$ after $672 \mathrm{~h}$ of exposure $\left(\mathrm{RH}=95 \%, \mathrm{~T}=22^{\circ} \mathrm{C}\right)$. In the cases where mass gain was $<0.05 \mathrm{mg} / \mathrm{cm}^{2}$, the metal loss was calculated from mass gain, based on the corrosion product composition determined by XRD (Fig. 2b), and (b) XRD patterns for AZ91 and RC AM50 samples exposed for $672 \mathrm{~h}$ in the presence of $70 \mu \mathrm{g} / \mathrm{cm}^{2} \mathrm{NaCl}$, in the absence and presence of $400 \mathrm{ppm} \mathrm{CO}_{2}$.
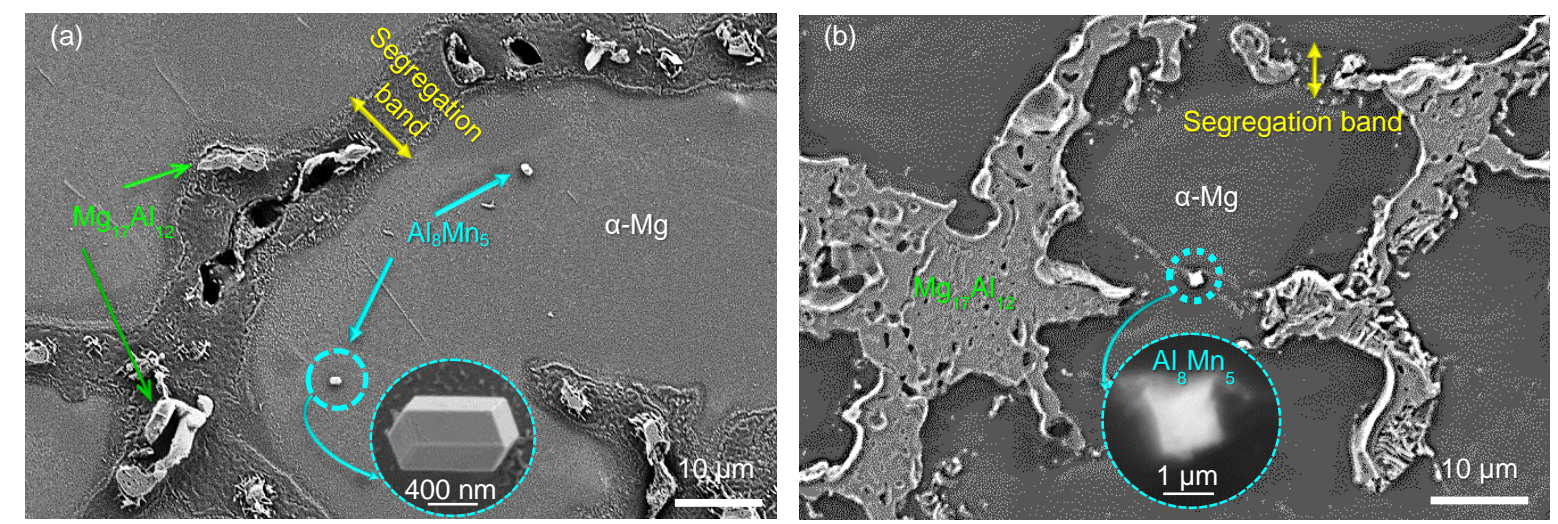

Fig. 3. Microstructure of semi-solid cast (a) AM50, and (b) AZ91 after polishing and etching. 

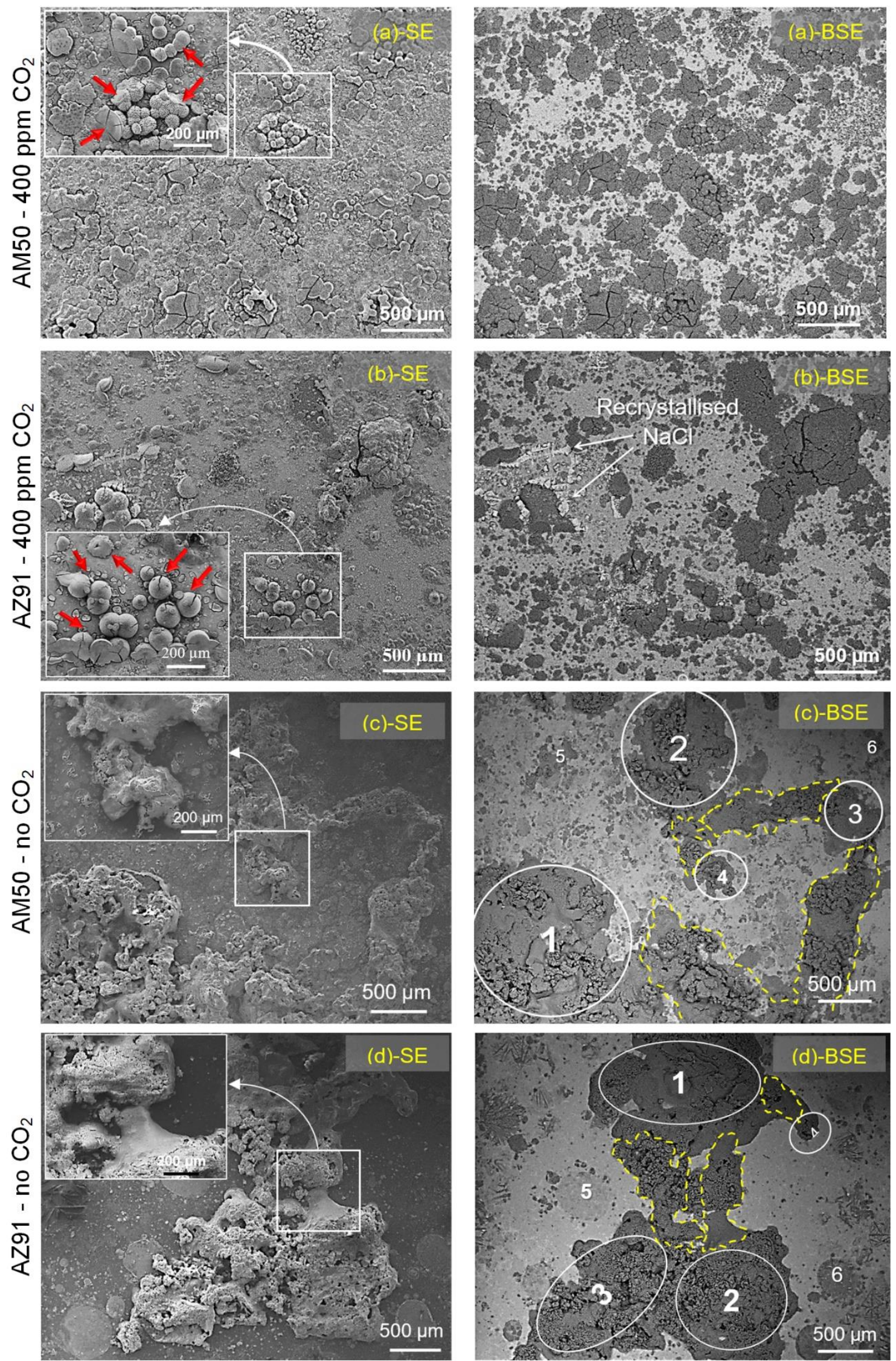

Fig. 4. Corrosion morphology after $672 \mathrm{~h}\left(70 \mu \mathrm{g} / \mathrm{cm}^{2} \mathrm{NaCl}, 95 \% \mathrm{RH}, 22^{\circ} \mathrm{C}\right)$ : (a) AM50-400 ppm $\mathrm{CO}_{2}$, (b) AZ91-400 ppm CO 2 , (c) AM50-no $\mathrm{CO}_{2}$, and (d) AZ91-no $\mathrm{CO}_{2}$. 

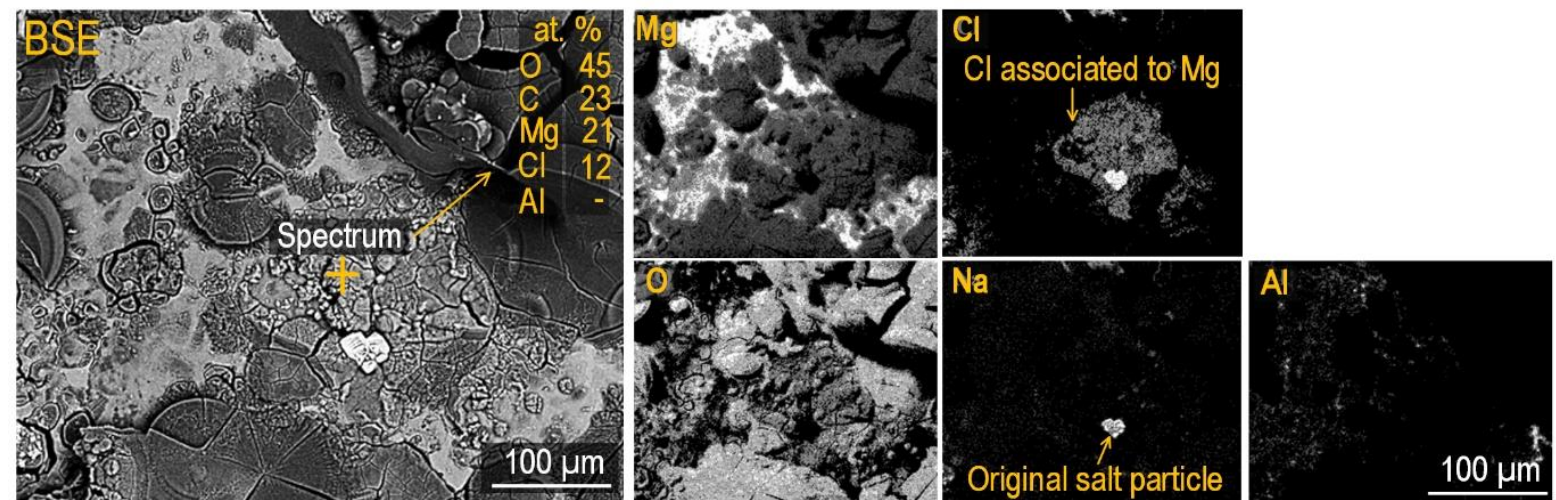

Fig. 5. EDX map and point analysis of an area close to a salt particle (alloy AM50 exposed in the presence of $400 \mathrm{ppm} \mathrm{CO}_{2}$ and $70 \mu \mathrm{g} / \mathrm{cm}^{2} \mathrm{NaCl}$ for $672 \mathrm{~h}$ at $22^{\circ} \mathrm{C}$ and $95 \% \mathrm{RH}$ ).
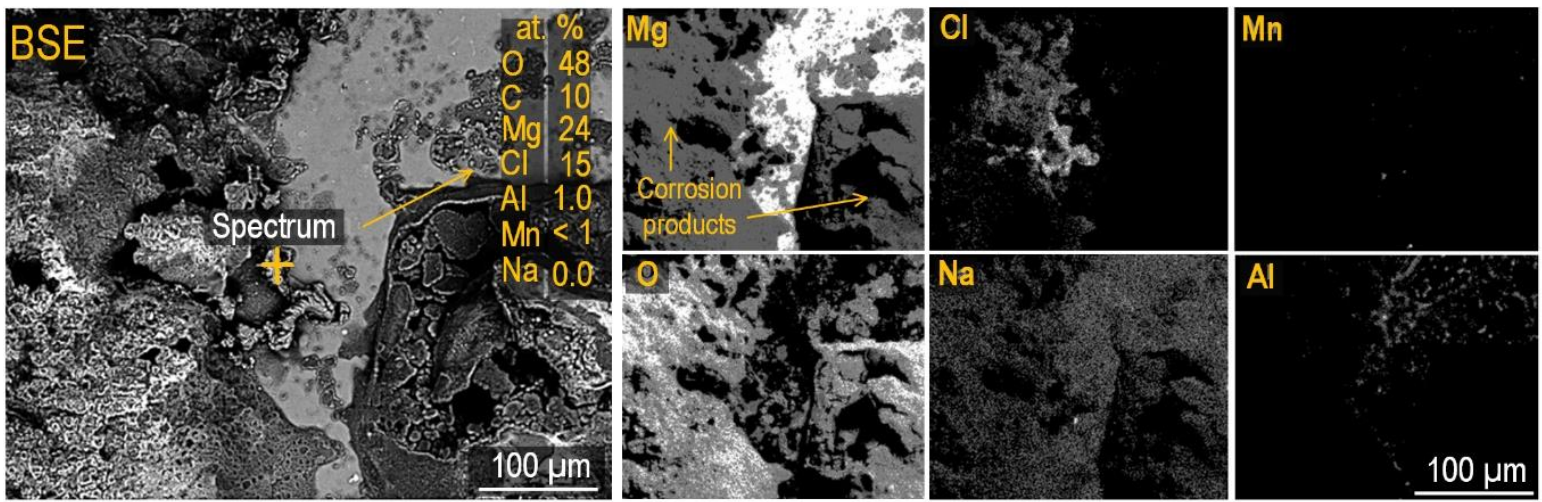

Fig. 6. EDX map and point analysis for the RC AM50 alloy exposed in the absence of $\mathrm{CO}_{2}$ and in the presence of $70 \mu \mathrm{g} / \mathrm{cm}^{2} \mathrm{NaCl}$ for $672 \mathrm{~h}$ at $22^{\circ} \mathrm{C}$ and $95 \% \mathrm{RH}$. Note the difference in redistribution of $\mathrm{Na}$ and $\mathrm{Cl}$ on the alloy surface.
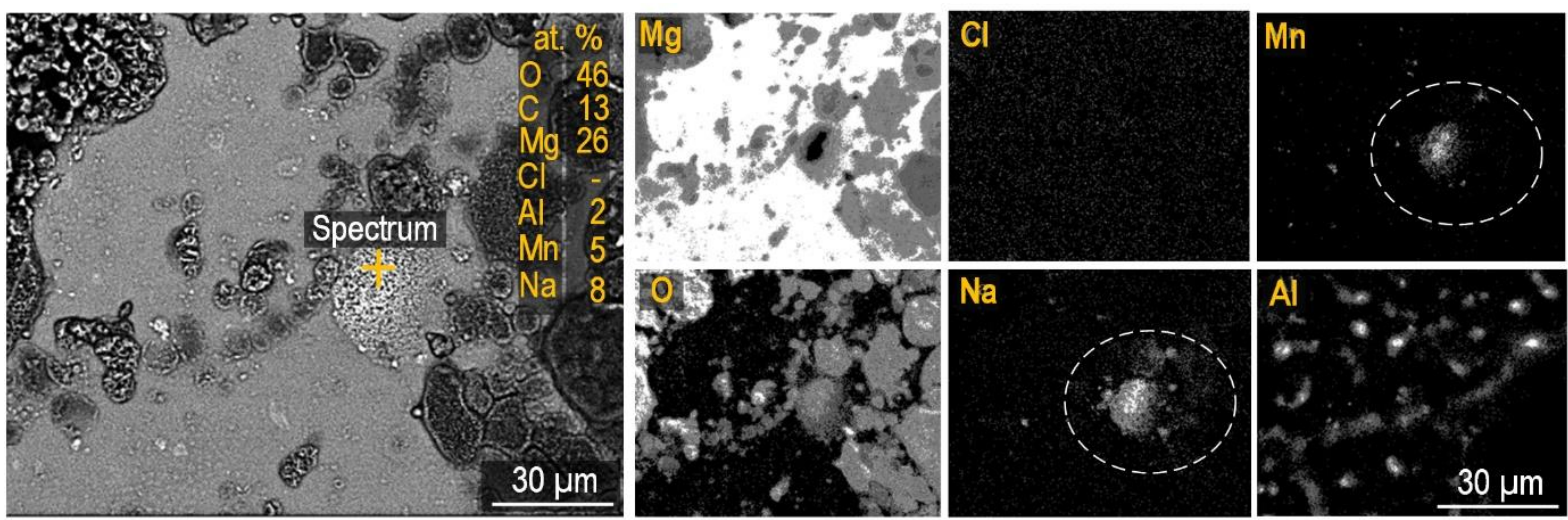

Fig. 7. EDX map and point analysis of alloy RC AM50 exposed in the absence of $\mathrm{CO}_{2}(70$ $\left.\mu \mathrm{g} / \mathrm{cm}^{2} \mathrm{NaCl}, 672 \mathrm{~h}, 22^{\circ} \mathrm{C}, 95 \% \mathrm{RH}\right)$. Note the accumulation of $\mathrm{Na}$ around the Mn-containing intermetallic particle on the alloy surface. 

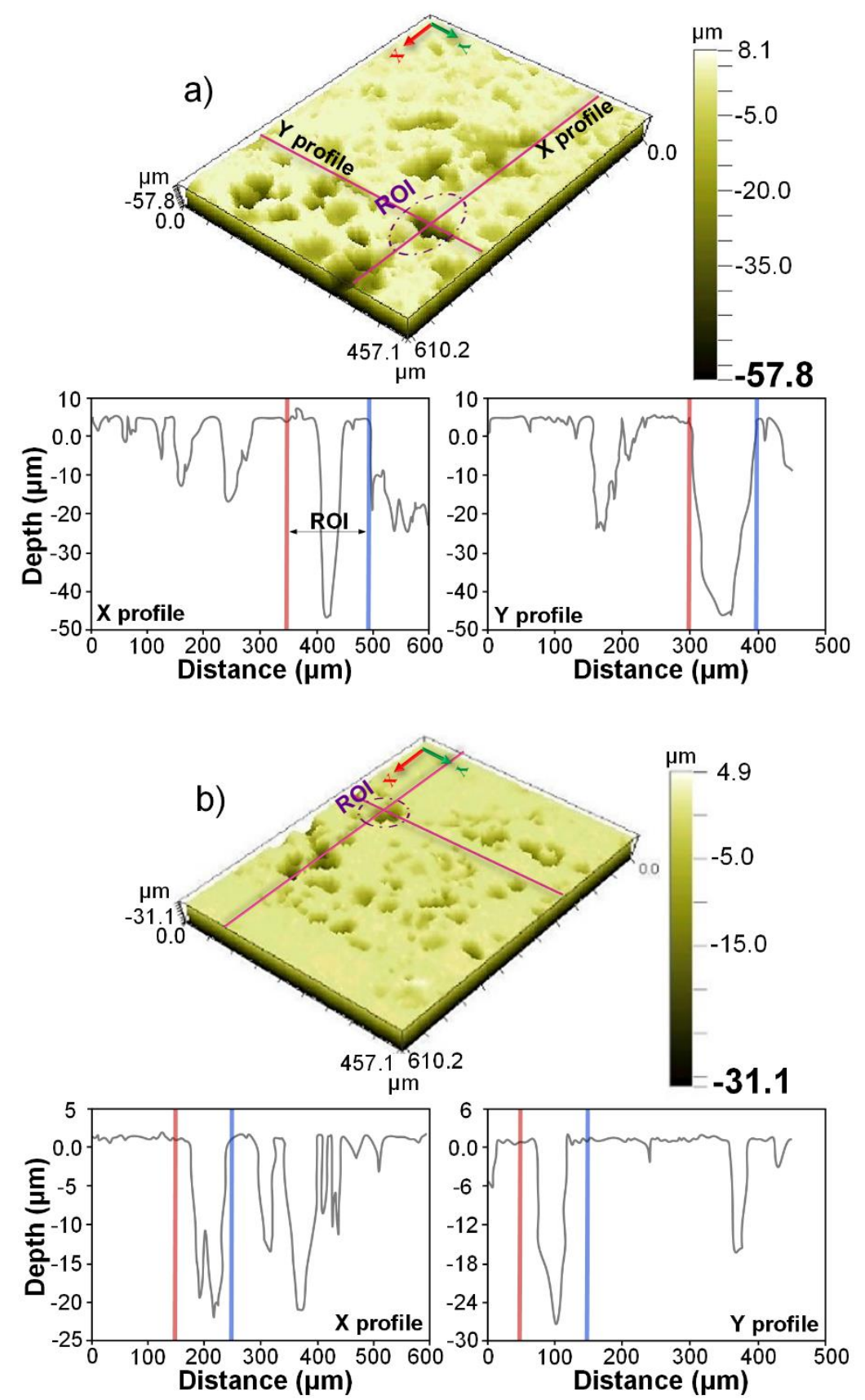

Fig. 8. 3D and 2D depth profiling (using interference microscopy) of alloys AM50 (a) and AZ91 (b), exposed in the presence of $400 \mathrm{ppm} \mathrm{CO}_{2}$ after corrosion product removal. 

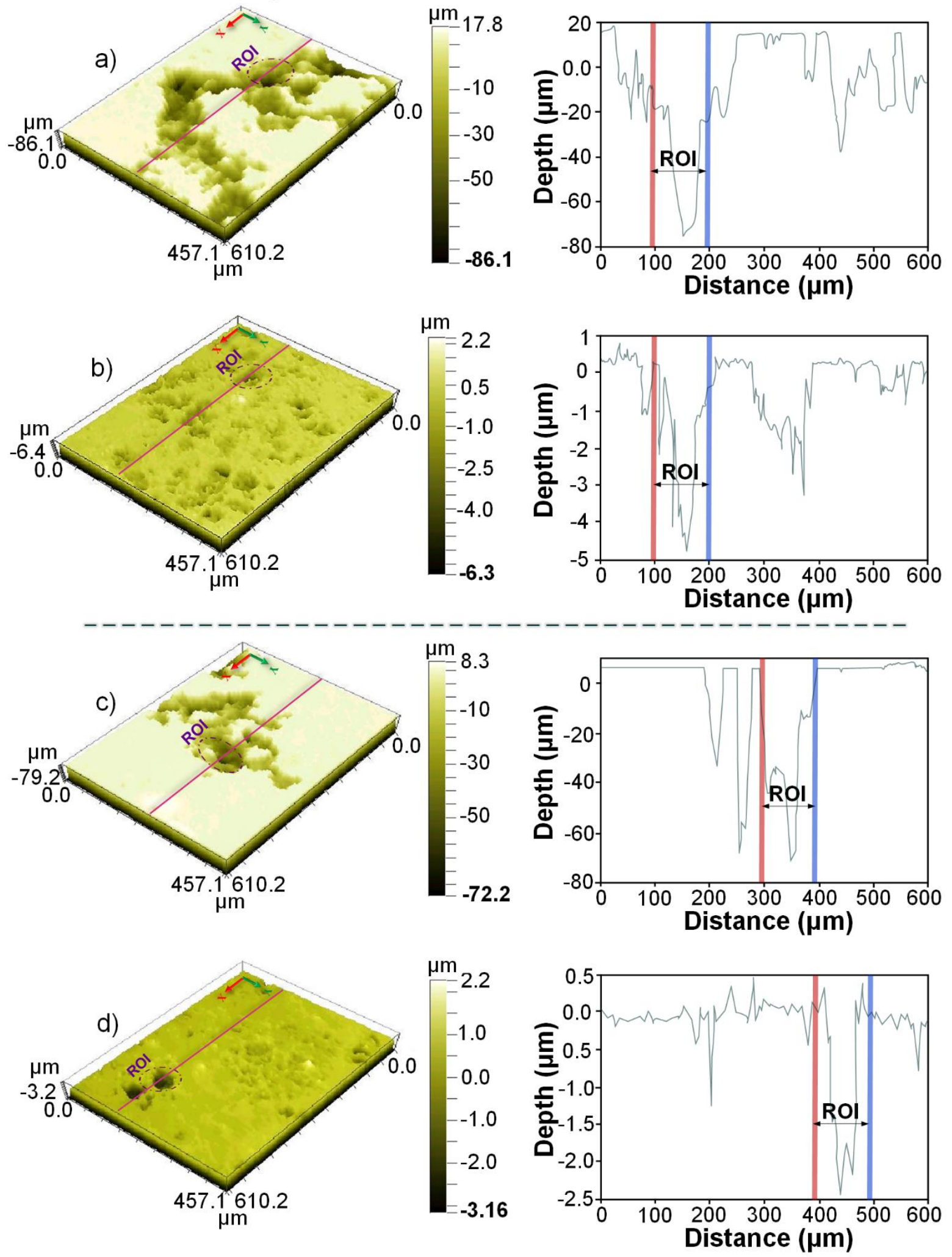

Fig. 9. 3D and 2D depth profiling (using interference microscopy) of alloy AM50 (a) and (b) and alloy AZ91 (c) and (d) exposed in the absence of $\mathrm{CO}_{2}$, after corrosion product removal. 
a)

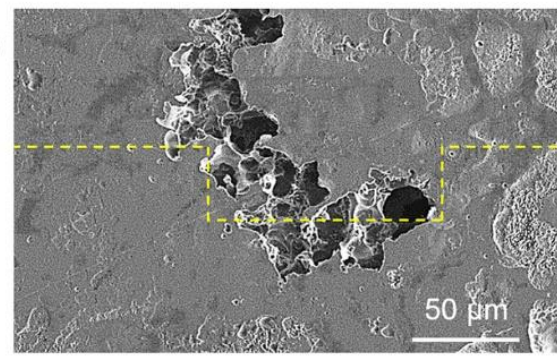

b)

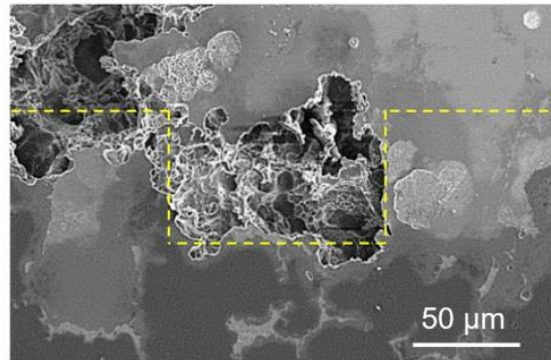

c)

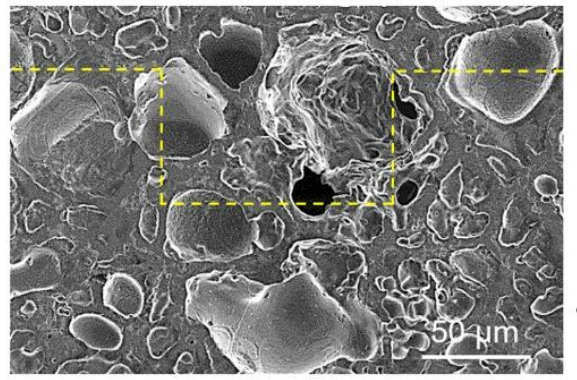

d)

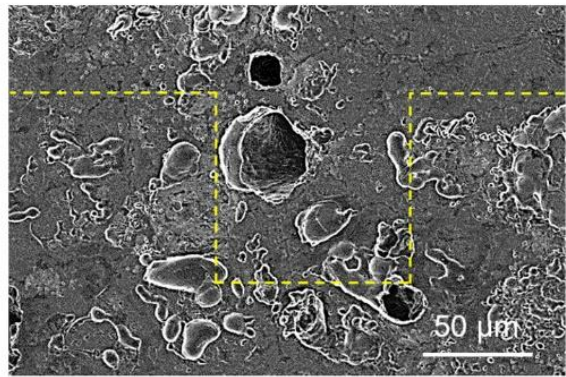

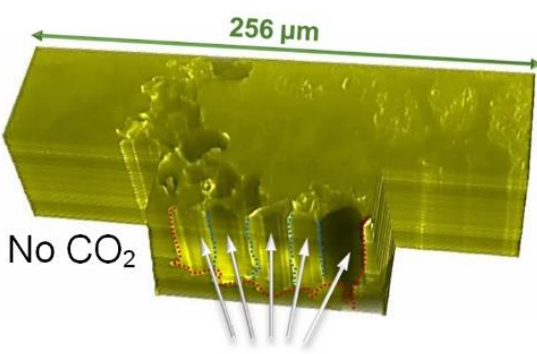
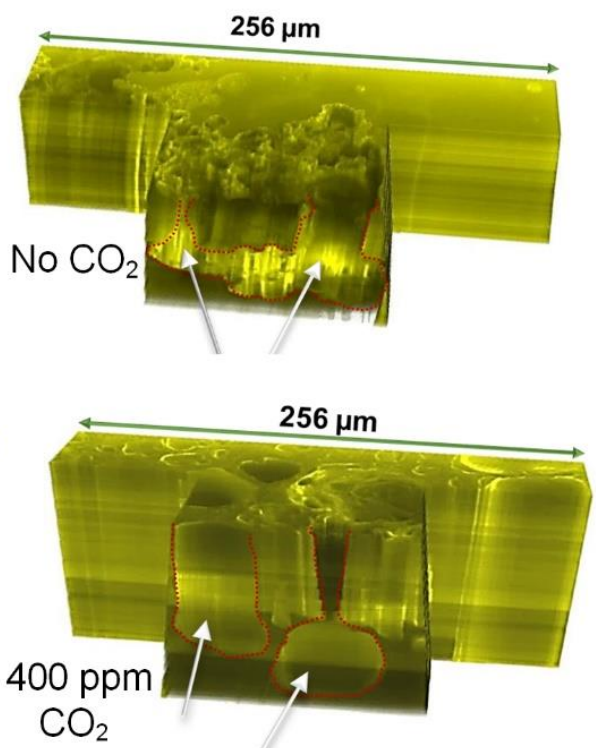

$256 \mu \mathrm{m}$

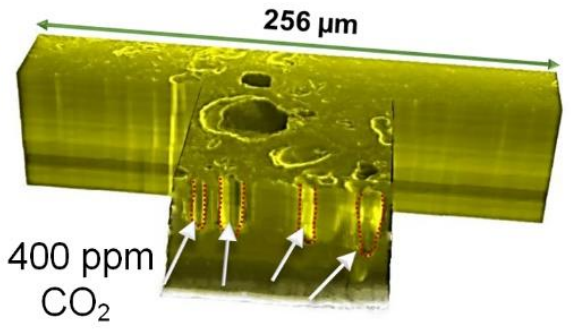

Fig. 10. 3D imaging (using FIB and SEM; see Fig. 1) of localised corrosion formed on semisolid cast alloy AM50 and AZ91 exposed at $95 \% \mathrm{RH}$ and $22^{\circ} \mathrm{C}$ in the presence of $70 \mu \mathrm{g} / \mathrm{cm}^{2}$ $\mathrm{NaCl}$ for $672 \mathrm{~h}$, (a) AM 50-absence of $\mathrm{CO}_{2}$ (b) AZ91-absence of $\mathrm{CO}_{2}$, (c) AM50-presence of $\mathrm{CO}_{2}$, and (d) AZ91-presence of $\mathrm{CO}_{2}$.
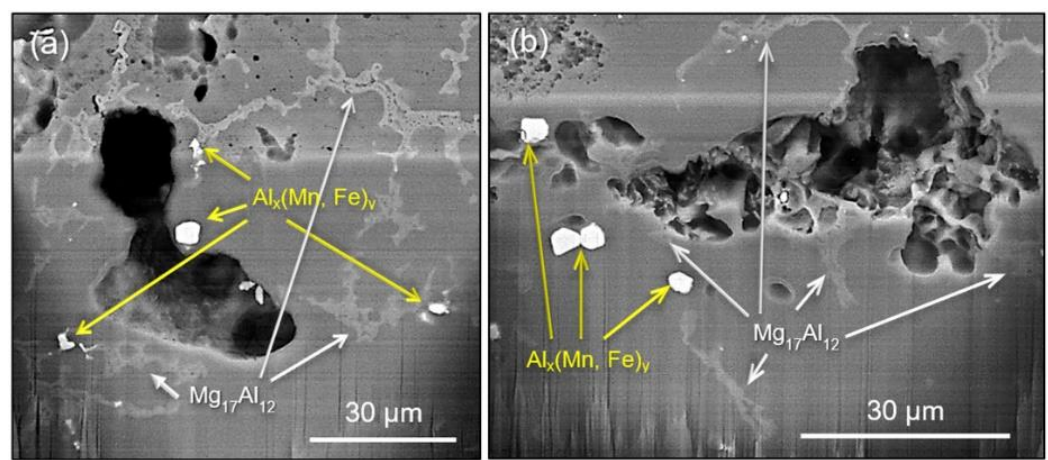

Fig. 11. BSE cross-sectional micrographs of alloy AZ91, exposed in the presence of $70 \mu \mathrm{g} / \mathrm{cm}^{2} \mathrm{NaCl}$ (a) in the presence, and (b) in the absence of $\mathrm{CO}_{2}$, after removal of the corrosion products. 


\section{Tables}

Table I. Alloy composition (wt\%). Balanced with Mg.

\begin{tabular}{lllllllllll}
\hline Material & $\mathrm{Al}$ & $\mathrm{Zn}$ & $\mathrm{Mn}$ & $\mathrm{Si}$ & $\mathrm{Fe}$ & $\mathrm{Cu}$ & $\mathrm{Ni}$ & $\mathrm{Ca}$ & $\mathrm{Pb}$ & $\mathrm{Sn}$ \\
\hline AM50 & 5.0 & 0.01 & 0.25 & 0.01 & 0.0016 & 0.0010 & 0.0007 & n.a. & n.a & n.a \\
AZ91 & 9.4 & 0.75 & 0.18 & 0.07 & 0.0074 & 0.0042 & 0.0007 & 0.0005 & 0.0011 & 0.0008 \\
\hline
\end{tabular}

Table II. Mass gain of semi-solid cast alloys AZ91 and exposed for $672 \mathrm{~h}$ at $22.00^{\circ} \mathrm{C}$ and $95.0 \% \mathrm{RH}$.

\begin{tabular}{cccc}
\hline & & \multicolumn{2}{c}{$\begin{array}{c}\text { Average dry mass gain } \\
\left(\mathrm{mg} / \mathrm{cm}^{2}\right)\end{array}$} \\
\cline { 3 - 4 } $\mathrm{CO}_{2}$ & $\mathrm{NaCl}\left(\mu \mathrm{gg} / \mathrm{cm}^{2}\right)$ & $\mathrm{AZ} 91$ & AM50* \\
& & 0.020 & 0.06 \\
$400 \mathrm{ppm}$ & 0 & 0.294 & 0.60 \\
$400 \mathrm{ppm}$ & 14 & 0.826 & 1.59 \\
$400 \mathrm{ppm}$ & 70 & 0.007 & 0.03 \\
0 & 0 & 0.310 & 1.18 \\
0 & 14 & 1.262 & 2.53 \\
\hline
\end{tabular}

* The gravimetric results for alloy RC AM50 have been published previously [16].

Table III. Area fraction of $\beta$-phase and Al content of $\alpha-\mathrm{Mg}$ (center of grain).

\begin{tabular}{cccccc}
\hline Alloy & Al content (wt.\%) & $\begin{array}{c}\text { Avg. } \beta \text { area } \\
\text { fraction } \%\end{array}$ & $\begin{array}{c}\text { Standard } \\
\text { error } \%\end{array}$ & $\begin{array}{c}\text { Avg. Al in } \alpha-\mathrm{Mg} \\
\text { (wt. } \%)\end{array}$ & $\begin{array}{c}\text { Standard error } \\
\text { (wt.\%) }\end{array}$ \\
\hline RC-AZ91 & 9.40 & $7.2^{*}$ & 0.5 & 3.09 & 0.14 \\
RC-AM50 & 5.00 & $2.1^{*}$ & 0.3 & 1.92 & 0.11
\end{tabular}

* The measurements were performed on 10 random regions on each material, each region having a surface area of $0.026 \mathrm{~mm}^{2}$. The segregation band was not included in the measurements. 